\title{
ARE OUR LABORATORY "STRAINS" REPRESENTATIVE SAMPLES OF TRYPANOSOMA CRUZI POPULATIONS THAT CIRCULATE IN NATURE?
}

\author{
M.P. DEANE* , A.M. JANSEN* ${ }^{*}$ R.H.R. MANGIA* A.M. GONÇALVES ${ }^{*}$ \& C.M. MOREL**
}

\begin{abstract}
About a dozen Trypanosoma cruzi strains` isolated throughout the endemic areas of Chagas' disease, mostly from human patients, less often from naturally infected triatomines, are maintained in several American and/or European laboratories, some for over 30 years. They have been and still are extensively used for studies on most aspects of the parasite and parasitehost interactions. These are what we could call "classical" or "laboratory" strains, of which the "Y" (Silva \& Nussenzweig, 1953) is probably one of the best examples. Recent studies involve increasing numbers of new isolates from new areas and new sources which include animal reservoir hosts.

Behaviour of the laboratory strains follows 3 distinct patterns that are maintained throughout the years (Brener. 1965; Brener, Chiari \& Alvarenga, 1974). Fresh isolates also tend to fall within the same limited number of "types" according to geographical areas and species and habitats of the original hosts (Andrade. 1973, 1976: Miles, 1983). The notorious stability of such patterns or types would suggest that various populations of the parasite were circulating independently (Miles et al., 1977) and would seem to give support to the assumptions that different "strains" produce different diseases in different areas (Andrade, 1973) such as it is generally accepted to be the case with the leishmaniases (Lainson \& Shaw, 1972). However, these assumptions do not take in consideration the recently reemphasized heterogeneity of $T$. cruzi (Dvorak, 1984), or the possibility of superinfections with heterologous strains and the permanence of such multiple infections (Deane et al., 1984a), or the overlapping cycles of transmission (Zeledon et al., 1970; Barretto \& Ribeiro, 1979) and consequent importance of the wild reservoir host in the epidemiology of the human Chagas' disease.
\end{abstract}

To evaluate the problem, two research lines are being pursued in our laboratories, based on the following premises:

a) Within any natural population of $T$. cruzi, subpopulations with different "competences" or potentialities may have better chances to multiply in a given environment (or host), while others are kept in check until chance opportunities favour their own amplification;

b) laboratory methods may favour the amplification of one subpopulation and through regular, standard schedules of passages, can possibly end with a highly selected and stable subpopulation.

Laboratory methods as selective factors. A brief review of the laboratory methods used by most workers (ourselves, inclusive) for the isolation and maintenance of $T$. cruzi strains is summarized in Fig. 1.

In contrast with most pathogenic protozoa, $T$. cruzi is, in many ways, an easy subject to work with: it is able to perform its complete cycles in any mammal or triatomine species and, "in vitro", in almost any type of cell culture and the most varied culture media. As a consequence, one may use whatever facilities one has in his own laboratory or field station, and it is convenience that frequently motivates choice. For instance, xenodiagnosis is largely preferred for primary isolation from the vertebrate host not only because it is assumed to be the most sensitive but because it is very convenient, especially for field work. Some triatomine species (e.g. Rhodnius prolixus) have been favoured simply because they are more prolific and easy to colonize than others.

The laboratory mouse is not only a means to "clean" and/or amplify a population isolated by xenodiagnosis and a most convenient manner of maintaining strains, but it has played an essential role in the characterization of these strains.

"Adaptation" to the mouse seems to be a primary concern of most workers. Before the characterization of a strains is started. weeks or months may be spent in trying to adapt it to mice, through various schemes of passage, the success being achieved when a patent infection with a measurable parasitemia is produced. It is often stated that a strain was initially of "low" virulence and that this increased as the number of passages increased (e.g., the Y strain, Silva \& Nussenzweig, 1953) or that strains that could not be adapted were dropped out of the study (e.g. Schlemper Jr, 1982). It is usually not clear if attempts had been made to detect a subpatent infection and the mouse found to be actually unsusceptible. In their

This work was supported by grants from the Conselho Nacional de Desenvolvimento Científico e Tecnológico, CNPq, Brazil, from the UNDP/World Bank/WHO Special Programme for Research and Training in Tropical Diseases and Financiadora de Estudos e Projetos, FINEP, Brazil.

Instituto Oswaldo Cruz, *Departamento de Protozoologia, **Departamento de Bioquímica e Biologia Molecular, Caixa Postal 926, 20000 Rio de Janeiro, RJ, Brazil.

- Although many workers are now adopting for T. cruzi the nomenclature proposed for Salivarian trypanosomes (W.H.O., 1978), the term "strain" is still largely used to signify a sample of the parasite population taken at a given moment from a given host and maintained thereafter by passages in the laboratory (Fig. 1). 


\begin{tabular}{llll} 
"Wild" population $\begin{array}{c}\text { of } \\
\text { Trypanosoma cruzi }\end{array}$ & "STRAINS": & isolation \& maintenance \\
\cline { 2 - 3 } & (samples) & $\begin{array}{l}\text { (primary } \\
\text { isolation) }\end{array}$ & (stocks \& lines)
\end{tabular}

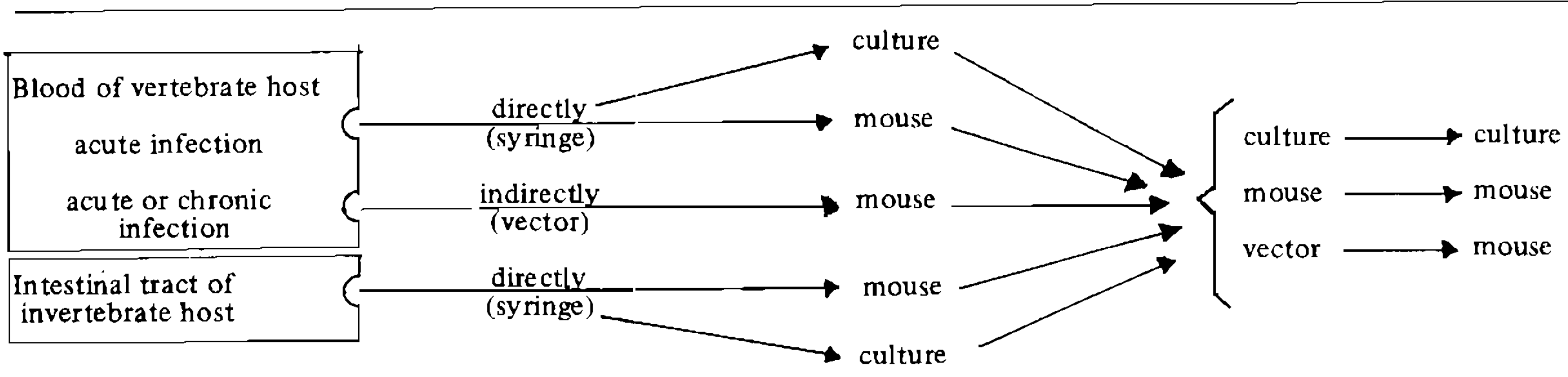

Fig. 1: scheme of the different methods in general use for the isolation of Trypanosoma cruzi from natural sources, and its main tenance in the laboratory. Although the term "strain" is still largely used as indicated, several workers are adopting the nomenclature proposed for the Salivariam trypanosomes (Bull, W.H.O., $56: 467-480,1978$ ), as above in ( ).

efforts to adapt strains to the mouse, some workers resort to new-born, gamma-irradiated or otherwise immune-depressed animals.

For maintenance in mice there is a tendency to standardize the inocula, the intervals between passages, the age (or weight) and sex of the mice. Several laboratories in Brazil adopt the scheme $1-1,5 \times 10^{5}$ bloodstream trypomastigotes taken on the day of peak parasitemia and injected in the peritoneum of $18-22 \mathrm{~g}$ male albino mice; the intervals vary according to the type of parasitemic curve previously established for each strain during the period of adaptation.

Strain characterization on "morphobiological" basis reflect the interrelation in the binomial parasite-mouse after the afore mentioned period of adaptation and of the stabilization of infections through the padronized passages. Special passages are sometimes made for the purpose, using groups of inbred mouse strains (e.g. Brener, Chiani \& Alvarenga, 1974; Carneiro, 1982).

Many variants can be introduced in the scheme presented in Fig. 1. Several passages from one line of maintenance to the other are made when one of them has been or is at risk of being lost, e.g., when mice died or are dying over the weekend or the cultures become contaminated or seem to be losing their infectivity, and so on.

Antigenic characterization and the more recently introduced methods of typing by biochemical markers usually require relatively large and clean (i.e. free from contamination by other cells) populations of the parasite which can be obtained more easily in cultures, and these may have been started from the original wild population or the primary isolate or, more often, anywhere and anytime along the lines of main tenance.

Following improvements of techniques for cryopreservation, there is an increasing number of laboratories that preserve strain "stabilates", this being a very convenient way of (presumably) preserving the qualities of a given sample and avoiding the time and material-consuming methods of regular passages which are also more prone to result in mix-ups. When defrozen, stabilates are usually subjected to a period of readaptation to mouse or culture.

Through this brief review* one can easily become aware of the various opportunities for selection. Some of these have been demonstrated in our laboratories using experimental double infections in mice and in the opossum Didelphis marsupialis.

The observations were mostly with 2 stable "laboratory strains" - Y and F - each producing in mice a characteristic and predictable type of infection under main tenance conditions (Deane et al., 1984a). They can also be distinguished by the characteristic electrophoretic profiles of their GPI isozyme and their kDNA fragments after digestion by the EcoRI restriction enzyme (Deane et al, 1984c; Gonçalves et al, 1985). These biochemical markers were unchanged when each strain was separately passaged according to various schemes that included culture, mouse and vector in succession or alternately (Mangia, Gonçalves \& Deane, 1983); they also proved to be capable of identifying both strains even when one of them represented only $1 \%$ of the total cell population in artificial mix tures (Gonçaives et al., 1985).

In a series of experiments (Deane et al., 1984) inoculations of the 2 strains were made separately after various intervals and recuperation of the parasites was either by direct hemoculture or with an intermediate passage in irradiated mice; through schizodeme and zymodeme analyses of the recuperated

* A number of papers dealing with $T$. cruzi strains have been revised, but since the methods are those in general use, most references are omitted. 
population both strains were identified in less than $1 / 4(\sim 22 \%)$ of the samples, what means that in over $3 / 4$ of the samples taken from mice that had received a double infection only one of the strains could be identified. The $\mathrm{F}$ strain was the only one to be identified in $\sim 56 \%$ of the reisolated samples. The $\mathrm{Y}$ population was revealed (alone or together with F) whenever the blood sample of the original mice had been taken within a month or less of its inoculation and had been amplified through an intermediate mouse passage before culturing. As discussed elsewhere (Deane et al., 1984 a) these results probably reflect the differences in the type of infection produced by each strain in mice: the early and limited acute phase of the $Y$ and, on the other hand, the much prolonged patent infection of the $F$.

The above interpretation was further supported by the results of other experiments involving mixed inocula of equivalent numbers of $Y$ and $F$ strains; the two were separated within a relatively short time by different schedules (weekly or monthly). of mouse passages. Identification of the strains in the reisolates was by their zymodeme and schizodeme and, also, by the characteristic type of infection they produce in mice (Deane et al., 1984b).

Predominance of one strain in an isolate probably can be perpetuated through the maintenance period: in our experiments, one sample in which only the $\mathrm{Y}$ strain had been identified maintained this singularity after 7 months of weekly mouse passages. As already emphasized the end result may be a very stable and (at least apparently) homogeneous population. As mentioned, in the above experiments culturing favoured amplification of the $F$ population. Before strain identification the reisolated samples had been maintained in culture for relatively short periods: about 2 fortnightly passages in NNN and 2-3 weekly passages in LIT (totalling $\sim 7$ weeks). Later and incidentally, it was verified that a prolonged period in culture may be necessary to reveal a strain that was started as a minority in the reisolation sample. An example of this is illustrated in Figs. 2 and 3, showing EcoRI restriction profiles of kDNA of parasites in reisolates taken from animals (opossums in this case) that had received the $Y$ and $F$ strains in equivalent numbers, in the same inoculum; the $F$ strain alone was revealed by the 1 st schizodeme analysis, made when the parasites had been in culture for $\sim 2$ months; the $Y$ strain only appeared (together with $F$ ) in the 2 nd analysis, when a 19 month period (more than 20 passages) had elapsed (Mangia et al., 1984).

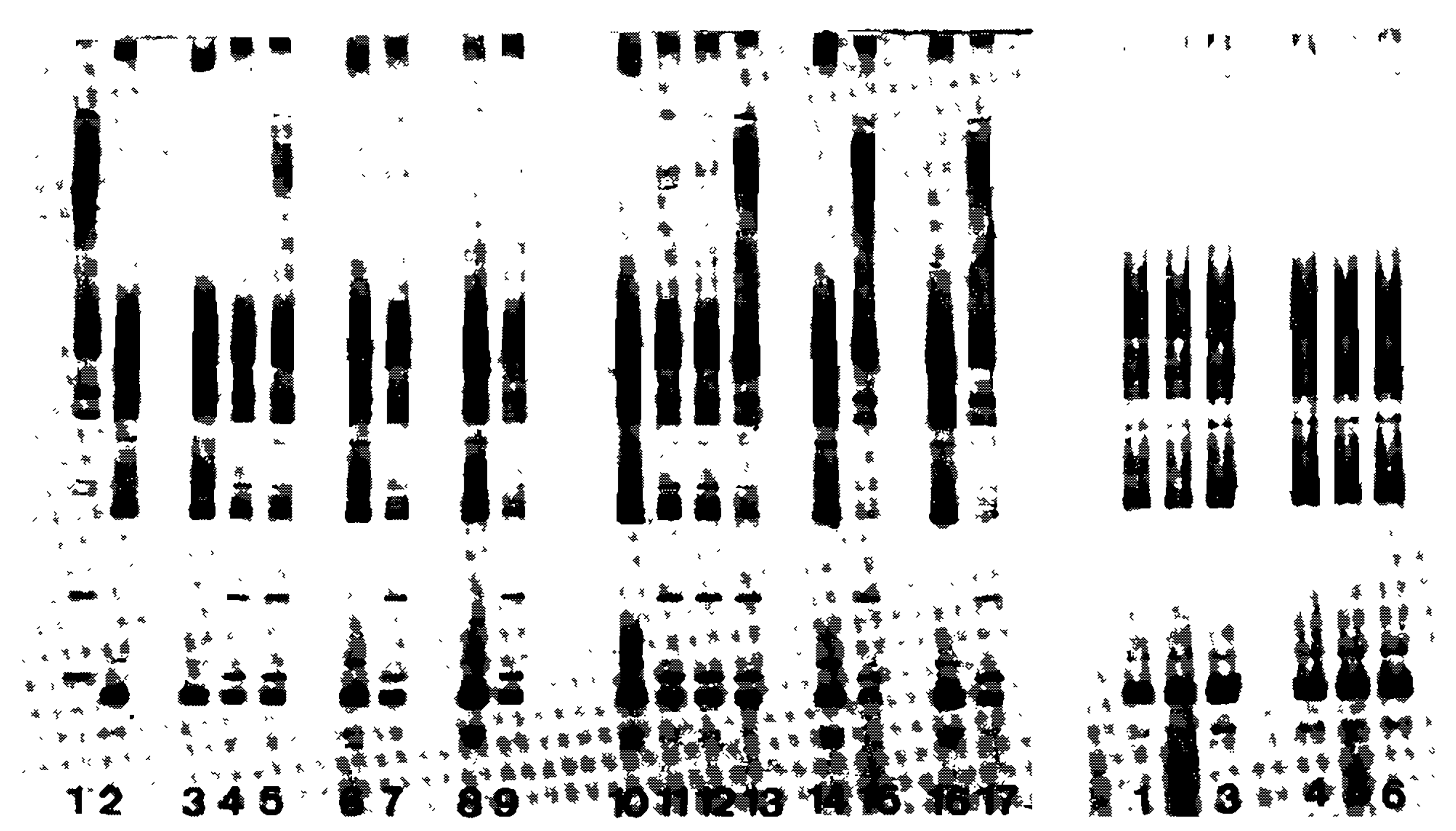

Figs. 2 \& 3: schizodeme analyses with the EcoRI restriction enzyme, of Trypanosoma cruzt populations recuperated from opossums experimentally infected with mixed inocula of the $Y$ and $F$ strains.

Fig. 2 - Lanes 1 \& 2: Y and F controls. Lanes $3-9$ and $10-17$, opossums Nos. 44 and 45 , respectively; Lanes $3-5$ and $10-13$, parasites recuperated by direct hemoculture; $6 \& 7$ and 14 $\& 15$, by mouse sub-inoculation; $8 \& 9$ and $16 \& 17$, by xenodiagnosis.

Fig. 3 - Lanes 1 - 3, opossum No. 44;4-6, opossum No. 45: reisolation by hemoculture, mouse sub-inoculation and xenodiagnosis, for each, in that order.

In both Figs., all lanes in which the F strain appears alone $(3,6,8,1014 \& 16$ in Fig. 2 and all those in Fig. 3) correspond to analyses made when the parasites had been main tained in cultures for 2 months. The presence of both $Y$ and $F$ strains was revealed only after a much longer period of sub-culturing (see text).

The above results are a strong warning against conclusions that the schizodeme or zymodeme has changed after prolonged subculturing when one has not started with cloned populations (Romanha et al., 1979).

T. cruzi strains in a natural reservoir host. Our 2 nd line of investigation deals with the behaviour of laboratory strains in the opossum Didelphis marsupialis and of strains naturally occurring in this marsupial when introduced in mice and (laboratory reared) opossums. Results of experimental infections 
by laboratory strains $\mathrm{Y}, \mathrm{F}$ and $\mathrm{F} 1$ have been partially discussed (Deane et al., 1984c) and a detailed account is in preparation.

As soon as it outgrows the embryonic stage of its postnatal development, the opossum is remarkably resistant to inocula that kill adult mice within 15 days. Strains such as $Y$ and $F 1$, that are among the most virulent for mice, produce in the opossum a very transient and low level patent infection, during which one or more of the parasitological diagnostic methods (direct blood examination, mouse subinoculation, hemoculture and xenodiagnosis) may be positive. Thereafter and for quite prolonged periods, the parasites elude every reisolation attempt. This hidden infections can be revealed under some circumstances, but apparently some opossums may, in time, actually get rid of them.

On the other hand, the F strain and strains isolated from naturally infected opossums produce, in laboratory reared specimens, infections that persist indefinitely, sometimes with alternate patent and subpatent periods. This is also the case with natural infections that have been followed for various periods.

According to Barretto's (1964) and our own experience, bloodstream trypomastigotes of naturally infected opossums are non-infective to the mouse. This host may be infected with feces of triatomines used for xenodiagnosis on the opossums, but, even with very heavy inocula of metacyclic forms (from bugs or cultures), the infection is very seldom patent (Barretto et al., 1964; Yoshida, 1983; Deane, Lenzi \& Jansen, 1984); the parasites can be recuperated through xenodiagnosis and hemoculture from the chronically infected mice.

In short, strains recently isolated from naturally infected opossums have very little virulence for mice. Since, as afore mentioned, laboratory strains most virulent for mice are little infective for the opossum, one can assume that vertebrate hosts are able to select different sub-populations from an heterogenous natural T. cruzi population.

Thinking in terms of isolation methods, one could expect that the laboratory mouse is able to amplify subpopulations which have their multiplication restrained in the natural host, and vice-versa.

Recent observations in our laboratories are here described with some detail, to illustrate a process of selection and amplification of a subpopulation that was in minority in the original population.

Attempting to understand the reasons for the low susceptibility of the opossum to the $Y$ strain, this was submitted to several tests in which the control was an opossum strain, received from Nobuko Yoshida (from the State Medical School, São Paulo) as a culture labelled "strain G" and christened as "G-N" in our laboratories. Here strain GN behaved exactly as described by Yoshida (1983), producing high rates of metacyclogenesis in cultures and in triatomines and only sub-patent infections in mice, even after heavy inocula of metacyclic trypomastigotes. In our laboratories it has been maintained along 2 lines, culture passages and alternate mouse $\rightarrow$ triatomine passages. From the $1^{\text {st }}$ of these lines the metacyclic trypomastigotes were used as controls in one of the above mentioned tests with the $Y$ strain and which consisted in evaluating infectivity to opossum macrophages "in vitro". No difference were detected between the 2 strains and both underwent more than one intracellular cycle in the macrophages, with production of large populations of trypomastigotes (Thomaz \& Deane, 1983).

The trypomastigotes of the G-N strain were harvested and inoculated in the peritoneum of several mice producing a patent infection with low parasitemia within a few days; the parasitemia increased in the next passages and the mice are now dying within 15 days. This line is labelled "G-N-op. $\phi \rightarrow$ mouse". At the $26^{\text {th }}$ passage along this line, blood cultures were obtained for zymodeme and schizodeme analyses and comparison with the first line (see above) of maintenance of the "original G-N". Results in Figs. 4 and 5 are sufficient to illustrate our point. Our interpretation is that a subpopulation was selected at the macrophage culture step and amplified in the mouse passages. More details and results of studies in progress that, among other things aim to test our hypothesis that the natural host (opossum) can restore the original population, shall be published (Thomaz et al., in preparation).

We think that adaptation to, and maintenance in the laboratory mouse is perhaps the most important single factor in strain selection.

However, several other factors may be involved, such as, for instance, different susceptibilities of the triatomines in relation to different populations of T. cruzi (Perlowagora-Szumlewicz \& Muller, 1979, 1982; Garcia \& Dvorak, 1982), strain differences in thermosensitivity (Neva, Malone \& Myers, 1961; Brener et al., 1976), and so on.

Work with clones has detected wide range variations within strains, involving schizodeme (Morel et al., 1980), generation time and type of infection in the mouse (Engel et al., 1982), specific antigens (Bongertz \& Dvorak, 1983), amount of $k$ and N-DNA (Dvorak et al., 1982), and other parameters. Although clones are themselves artificially selected populations, investigations such as those of Dvorak and coworkers clearly demonstrate the heterogeneity of apparently stable strains and emphasize the problem of laboratory selection.

The recent discovery of a double cycle of $T$. cruzi in the opossum (Deane, Lenzi \& Jansen, 1984; Lenzi, Jansen \& Deane, 1984; Lenzi et al., 1984, this Symposium) opens to investigation a new chapter in the complex topic of dispersion and selection of the parasite populations. 


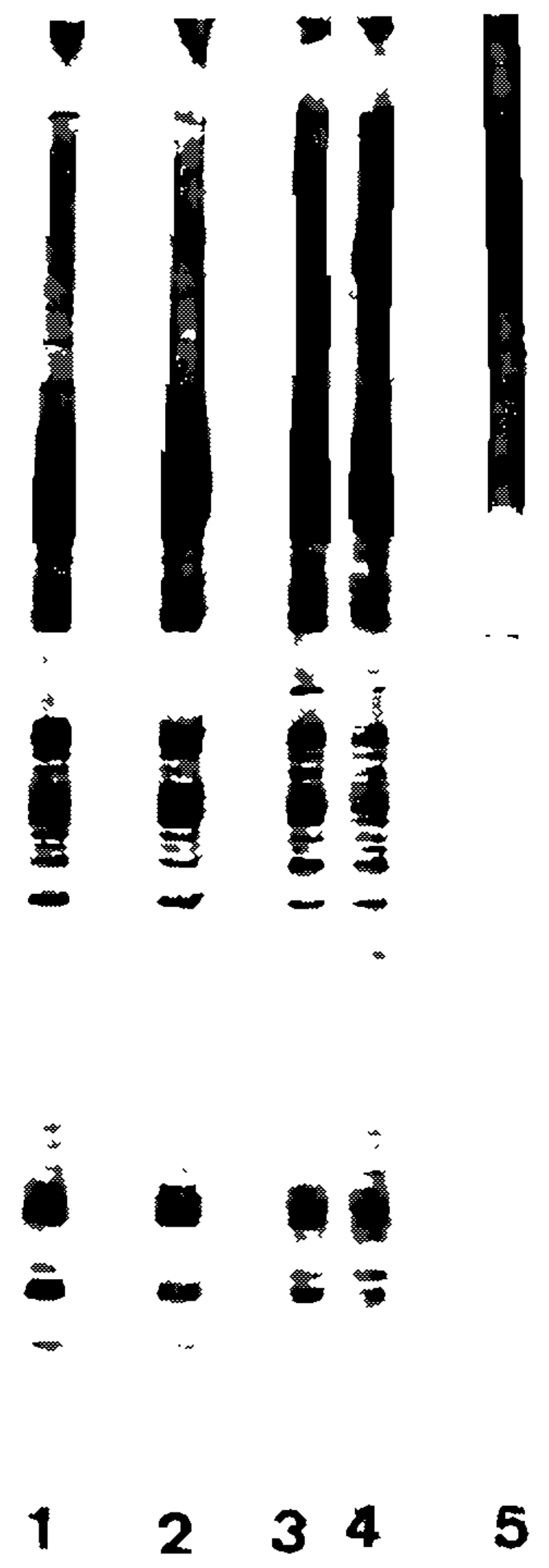

Fig. 4: schizodeme analyses with the EcoRI restriction enzyme, of Trypanosoma cruzi, opossum strain G-N. Lane 1: "original" line kept in culture; Lane 2: culture ("original") $\rightarrow$ mouse $\rightarrow$ culture passages: Lane 3 and 4 : culture ("original") $\rightarrow$ opossum; reisolations by hemoculture and xenodiagnosis, respectively; Lane 5 : Line "G-Nop. $\mathrm{m} \phi \rightarrow$ mouse" (see text). Discrete differences appeared after an opossum passage (lanes $3 \& 4$ ). The population that is now virulent for mice (lane 5) presents and entirely different profile.



Fig. 5: variation of the glucosephosphate isomerase (E.C.5.3.1.9, GPI) isozyme of Trypanosoma cruzi, opossum strain G-N: 1 -- "original" line, kept in culture; 2 and 3: culture ("original") $\rightarrow$ opossum, reisolations by hemoculture and xenodiagnosis, respectively: 4: line " $\mathrm{G}-\mathrm{N} \rightarrow$ op. $\mathrm{m} \phi$ $\rightarrow$ mouse". Compare with Fig. 4 and see text.

To conclude we wish to comment on the efforts to correlate $T$. cruzi strain and the different aspects of Chagas' disease in man. This could not be achieved up to now and may prove to be an exceeding difficult task, since all the variation is certainly the result of the interplay of variables related inclusively but not exclusively - to the parasite. However, it should be remembered that inconclusive results may be due to the fact that. once in troduced in our laboratories, strains cease to be replicas of what was circulating in the natural host.

\section{REFERENCES}

ANDRADE, S.G., 1973. Caracterização de cepas de Trypanosoma cruzi isoladas no Recôncavo baiano. Tese 123 p. Universidade Federal da Bahia.

ANDRADI:, S.G., 1976. Tentative for grouping different Trypanosoma cruzi strains in some types. Rev. Inst. Med. trop. Säo Paulo, $18: 140-141$.

BARRETTO, M.P. \& RIBEIRO, R.D., 1979. Reservatórios silvestres do Trypanosoma (Schizotrypanum) cruzi. Rev. Inst. Adolfo Lutz, $39: 25-36$.

BARRETTO, M.P.; SIQUFIRA, A.F.; CORRFA, F.M.A.; FERRIOLI FILHO, F. \& CARVALHEIRO, J.R., 1964. Estudos sobre reservatórios e vetores silvestres do Trypanosoma cruzi. VII: Investigaçōes sobre a infecção natural de gambás por tripanossomos semelhantes ao T. cruzi. Rev. Brasil. Biol., 24 :289-300.

BONGERTZ, V. \& DVORAK, J.A., 1983. Trypanosoma cruzi: antigenic analysis of cloned stocks. Am. J. Trop. Med. Hyg., $32(4): 716-722$.

BRENER, Z.. 1965. Comparative studies of different strains of Trypanosoma cruzi. Annals Trop. Med. Parasitol., 59 $: 19-26$.

BRFNFR, Z.: CHIARI, E. \& ALVARENGA, N.J., 1974. Observations on T. cruzi strains maintained over an 8 year period in experimentally inoculated mice. Rev. Inst. Med. trop. Säo Paulo, 16:32-38.

BRFNER, Z.; GOLGHER. R.R.: BERTF.LLI, M.S. \& TEIXFIRA, J.A., 1976. Strain dependent thermosensitivity influencing in tracelular differentiation of Trypanosoma cruzi in cell culture. J. Protozool., $23: 147-150$.

CARNEIRO, M., 1982. Caracterização biológica de amostras de Trypanosoma cruzi de diferentes zimodemas e esquizodemas. Tese. 90 p. Universidade Federal de Minas Gerais. 
DEANE, M.P.; JANSEN, A.M.; MANGIA, R.H.R. \& LENZI, H.L., 1984c. A study of experimental infections of the opossum Didelphis marsupialis with various strains of Trypanosoma cruzi. XI Reunião Anual, Pesquisa Básica em Doença de Chagas, Caxambu, MG. BI-39.

DEANE, M.P.; LENZI, H.L. \& JANSEN, A.M., 1984. Trypanosoma cruzi: vertebrate and invertebrate cycles in the same mammal host, the opossum Didelphis marsupialis. Mem. Inst. Oswaldo Cruz, 79 :513-515.

DEANE, M.P.; MANGIA, R.H.R.; PEREIRA, N.M.; MOMEN, H.; GONC ALVES, A.M. \& MORF L, C.M., 1984b. Trypanosoma cruzi: strain selection by different schedules of mouse passage of an initially mixed infection. Mem. Inst. Oswaldo Cruz, 79 (4): $495-497$.

DEANE, M.P.; SOUZA, M.A.; PEREIRA, N.M.; GONÇALVES, A.M.; MOMEN, H. \& MOREL, C.M., 1984a. Trypanosoma cruzi: Inoculation schedules and re-isolation methods select individual strains from doubly infected mice, as demonstrated by schizodeme and zymodeme analyses. J. Protool., 31 :276-280.

DVORAK, J.A., 1984. The Natural heterogeneity of Trypanosoma cruzi: Biological and Medical implications. J. Cell. Biochem., $24: 357-371$.

DVORAK, J.A.; HALL, T.E.; CRANE, M. ST. J.; ENGEL, J.C.; McDANIEL, J.P. \& URIEGAS, R., 1982. Trypanosoma cruzi: Flow cytometric analysis. I. Analysis of total DNA/Organism by means of mithramycin - induced fluorescence. J. Protozool., 29 (3):430-437.

ENGEL, J.C.; DVORAK, J.A.; SEGURA, E.L. \& CRANE, ST. J.M., 1982. Trypanosoma cruzi: Biological characterization of 19 clones derived from two chronic chagasic patients. I. Growth kinetics in liquid medium. J. Protozool., 29(4) :555-560.

GARCIA, E.S. \& DVORAK, J.A., 1982. Growth and development of two Trypanosoma cruzi clones in the arthropod Dipetalogaster moximus. Am. J. Trop. Med. Hyg., $31: 259-262$.

GONÇALVES, A.M.; CHIARI, E.; DEANE, M.P.; CARNEIRO, M.; ROMANHA, A.J. \& MOREL, C.M., 1985. Schizodeme characterization of natural and artificial populations of Trypanosoma cruzi as a tool in the study of Chagas' Disease, in Newton, B.A., ed., Application of Biochemical and Molecular Biology Techniques to Problems of Parasite and Vector Identification. Proceedings of an International Symposium. World Health Organization Geneva 8-10 November 1982. UNDP/World Bank/WHO Special Programme for Research and Training in Tropical Diseases, Geneva, Switzerland (in press).

LAINSON, R. \& SHAW, J.J., 1972. Leishmaniasis of the New World:Taxonomic problems. British Med. Bull, $28: 44-48$.

LENZI, H.L.; JANSEN, A.M. \& DEANE, M.P., 1984. New habitat of Trypanosoma cruzi in the vertebrate host. Xl Reuniâo Anual, Pesquisa Básica em Doença de Chagas, Caxambu-MG.

MANGIA, R.H.R.; GONÇALVFS, A.M. \& DEANE, M.P.. 1983. Strain characterization after different schemes of passage. $X$ Reunião Anual. Pesquisa Básica em Doença de Chagas, Caxambu-MG. BI-34.

MANGIA, R.H.R.; GONÇALVES, A.M.; MOREL, C.M. \& DEANE, M.P., 1984. Trypanosome cruzi: strain selection by laboratory methods induce wrong conclusions. XI Reuniāo Anual, Pesquisa Básica em Doença de Chagas, CaxambuMG. Bl-42.

MILES, M.A., 1983. The epidemiology of South American Trypanosomiasis - biochemical and immunological approaches and their relevance to control. Trans. R. Soc. Trop. Med. Hyg., 77:5-23.

MILES, M.A.; TOYE, P.J.; OSWALD, S.C. \& GODFREY, D.G., 1977. The identification by isocnzyme patterns of two distinct strain groups of Trypanosoma cruzi, circulating independently in a rural area of Brasil. Trans. R. Soc. Trop. Med. Hyg., 71 :217-225.

MOREL, C.; CHIARI, E.; CAMARGO, E.P.; MATTEI, D.M.; ROMANHA, A.J. \& SIMPSON, L., 1980. Strains and clones of Trypanosoma cruzi can be characterized by pattern of restriction endonuclease products of kine toplast DNA minicircles. Proc. Natl. Acad. Sci., 77 (11) :6810-6814.

NEVA, F.A.; MALONE, M.F. \& MYERS, B.R., 1961. Factors influencing the in tracellular grow th of Trypanosoma cruzi in vitro. Am. J. Trop. Med. Hyg., $10: 140-154$

PERLOWAGORA-SZLMLEWICZ, A. \& MULLER, A.L., 1979. Experiments in a scarch for an insect model for xenodiagnosis of chronic Chagas discase. Proceeding of the Congresso Internacional sobre Doença de Chagas, E-11-E-16, Rio de Janeiro.

PERLOWAGORA-SZUMLEWICZ, A. \& MULLER, A.C., 1982. Studies in search of a suitable experimental insect model in xenodiagnosis of hosts with Chagas' disease. I - Comparative xenodiagnosis with nine triatomine species of animals with acute infections by Trypanosoma cruzi. Mem. Inst. Oswaldo Cruz, $77: 37-53$.

ROMANHA, A.J.; SILVA PEREIRA, A.A.; CHIARI, E. \& KILGOLR, V. 1979. Isocnzymic pattern of cultured Trypanosoma cruzi: changes after prolonged subculture. Comp. Biochem. Physiol., 62:139-142.

SCHLEMPER, B.R., 1982. Caracterização de cepas do Trypanosome cruzi isoladas de pacientes com diferentes formas clınicas da Doença de Chagas. Tese. $131 \mathrm{p}$. Universidade Federal do Rio de Janeiro.

SILVA, L.H.P. da \& NUSSENZWEIG, V, 1953. Sobre uma cepa de Trypanosoma cruzi altamente virulenta para o camundongo branco. Folha Clin. et Biol, $20: 191-208$.

THOMAZ, N. \& DEANE, M.P., 1983. In vitro infection of Opossum (Didelphis marsupialis) macrophages with different strains of Trypanosome cruzi. X Reuniāo Anual, Pesquisa Básica em Doença de Chagas, Caxambu-MG, BI-63.

YOSHIDA, N., 1983. Surface antigens of metacyclic trypomastigotes of Trypanosoma cruzi. Infection and Immunity, 40 :836-839.

ZELËDÓN, R.; SOLANO, G.; SĀENZ, G.S. \& SWARTZ-WHLLDFR, J.C., 1970. Wild reservoirs of Trypanosoma cruzi with special mention of the opossum, Didelphis marsupialis in endemic area of Costa Rica. J. Parasitol.. $56: 38$. 